\title{
Gal Gangs, Worm Lessons, and Elephant Bones
}

Ann Bixel ${ }^{*}$

${ }^{1}$ Upper Arlington High School, Upper Arlington, Columbus, Ohio, 43221, USA

* Correspondence: ajlrbixel@gmail.com

(Received: 08/22/2021; Accepted: 10/28/2021; Published: 11/03/2021)

DOI: https://doi.org/10.37906/isteamc.2021.9

Abstract: Scientists today believe that many nonhuman animals possess emotions. Additionally, they find that emotions are not limited to mammals, but that birds, reptiles, and fish also have feelings. Studying animal emotions may be the key to understanding creatures' relationships with each other. In particular, what relationships do animals form when living in small groups? Ethologists observing animals in their natural habitats reveal many answers. First, animals in small groups employ a variety of leadership styles. Second, family relationships between parents and offspring, brother and sister, and elders and adolescents help the group survive and thrive. Third, when animals lose a member of their group, they appear to grieve in ways synonymous to humans. As they examine these relationships, animal behaviorists, including famed ethologist Marc Bekoff, help us dive deeper into the lives of animal communities so we can live with them in harmony with them.

Keywords: animal behavior; animal relationships; leadership; family relationships; grief

\section{Introduction}

Whether or not animals have emotions has been a long-standing scientific controversy in science. For centuries, scientists believed that animals had no emotions, and if they did it was impossible to prove. "Science requires more than intuition and instinct. It demands theories, experiments, data collection, outcome assessments, replication of results. Science can't merely know; it has to prove" acknowledges ethologist Marc Bekoff (2000) in his book The Smile of a Dolphin (p. 21).

That is until one of the first well known animal behaviorists, Charles Darwin, traveled to the Galapagos Islands to studied the finches and mockingbirds. Wanting to expand his knowledge of animals beyond the limits of traditional experimentation, Darwin was one of the first to observe animals in their natural habitats. As a result, scientists today believe that many nonhuman animals do have emotions and that emotions are not limited to mammals, but that birds, reptiles, and fish have feelings.

Studying animal emotions is the key to understanding creatures' relationships with each other. While the web of animal relationships is vast and intricate scientists are beginning to ask, what relationships do animals form when living in small groups?

\section{Research from the Field: Leadership}

Leadership style is one of several factors that has a direct impact on the group dynamic. How indeed do the leaders of these small animal communities influence the relationships in their groups? 


\subsection{Patriarchal Communities}

Small groups led by a patriarch typically have social hierarchies. For example, wolf packs usually consist of an alpha male and female. The alpha male dominates the males of the group while the alpha female dominates the other females. Thus, the pack also includes an omega male and female. While it seems like the biggest wolf would be the alpha and the smallest the omega, this is not always the case.

For years, Jim and Jamie Dutcher lived with and documented the behavior of the Sawtooth Pack in Idaho. After spending time with the wolves, they noticed that the pack's omega, Lakota, was much bigger than the alpha, Kamots. However, the Dutchers (2013) writes in their book The Hidden Life of Wolves that "Kamots was clearly the boldest of his littermates [at a young age]" (p. 65). Kamots carried his head and tail higher even as a pup so naturally there was no challenge when he assumed the role of pack leader. In contrast, the omega, Lakota, often acted like the court jester keeping morale high and initiating play. Though Lakota was often bullied, sometimes the pack's squabbles were transferred to him to be sorted out.

The Dutchers (2013) writes, "[W]hile it looks rough at times, dominance and submission are ritualized ways of maintaining order, cohesion, and unity" (p. 65). In groups with a social hierarchy, it is important that the leader maintains the roles so that the park can move as one.

\subsection{Matriarchal Communities}

However, groups with matriarchal leadership concentrate on fostering a sense of community. These matriarchal groups rely on a tightly knit, web-like network. The article "Matriarchal Societies in the Animal Kingdom" states that the "[r]emoval of one or more of these highly intelligent and extremely social animals, especially the matriarch, may have a devastating effect of the survival of the family group" (Southern Resident Killer Whales, para. 5).

For example, in both elephant herds and orca pods which are led by the biggest and/or oldest female, all sexually mature females will breed if they can, and the rest of the pod helps take care for the offspring together. In fact, the members of the group are sometimes direct descendants of their matriarch.

Bonobo apes take a different approach with their female-led communities by forming "gal-gangs". The bonobo females team up to exert power over the males in the group. In this way, the gal-gangs are often able to prevent the males from killing the babies of rival males. Additionally, the females are able to choose their mates and access better food.

\subsection{Variations}

There are many different types of leadership, and each species of animal leads differently. In fact, even amongst different groups of the same species, the leadership style will vary. Not all patriarch-led groups have strict social hierarchies, and not all matriarch-led groups are community-based. The expansive research on leadership's effect on small group relationships includes discoveries as various as the animals studied.

\section{Research from the Field: Family Groups}

The family groups within animal communities also defines how relationships play out.

\subsection{Parent-Child Relationships}

Parent-child bonds are created at an early stage so the young of a group can survive. The relationship between a parent and their offspring is that of teacher-student. Zoologist and conservationist, David Macdonald, writes in "Night School" about witnessing a mother fox teaching her offspring how to hunt for worms. It was tricky at first since the fox cub kept bouncing around the forest floor slipping on the mud. 
However, once his mother got his attention he slowly learned the skill of worm hunting. When the mother tugged a worm whose tail held onto an underground root, she demonstrated to the cub how to stroke the worm with a paw to soothe it so it would let go of its hold. Macdonald (2000) observed "in a few short minutes [the cub] had learned the principle--inept maybe, but now he foraged with adult style" (p. 49).

\subsection{Sibling Relationships}

Sibling bonds are also at play. Jim and Jamie Dutcher also documented a yearling female wolf helping her younger baby brother across a small river. The pup was a bit wary of the water, but the yearling playfully splashed the water with her paws. When the pup finally picked his way across, he was greeted with licks and wagging tail from his older sister. In this case, the job of confidence building fell not to the parent but to the older sibling.

\subsection{Elders}

Finally, elders oftentimes play the role of mediator in the group. In "Teenage Elephants Need a Father Figure", Lucy Freeman writes about adolescent elephants who were experiencing "musth" at a national park in South Africa. She defines musth as a "unique state to elephants, in which young males, usually in their 20s, are flooded with reproductive hormones" (para. 2). In this case they were acting aggressively to each other and other animals. In the wild, "the normal safeguard is when an elephant in musth encounters a bigger bull elephant, he immediately drops out of musth as he knows his testosterone cannot compete," writes Freeman (para. 4). An ecologist at the park decided that there were two options: to neuter the adolescents or to introduce older male elephants. The reserve decided that the best course of action was to fly six bull elephants out "and literally within hours, the teen thugs had dropped out of musth" (para. 7). Clearly, elders bring incredible peace and wisdom to their group.

\subsection{Contributions}

Thus far, scientific observation shows that parents educate their offspring, siblings support each other, and elders mediate scuffles. Clearly family relationships help the group not only survive, but also thrive.

\section{Research from the Field: Losing a Member of the Group}

Inevitably, when an animal dies, their community needs to let go of these important bonds. We can never know exactly why or how an animal grieves, but we can make inferences from what we observe.

\subsection{Emotional Expression}

In Jessica Pierce's 2018 Smithsonian article "Do Animals Experience Grief?" she details accounts of how small groups of animals display a sense of loss. For example, she describes chimpanzees taking part in death-related behavior. Scientists saw chimpanzees checking the pulse and cleaning the fur of a dead chimp. Following this, the chimps refused to go to the area where their groupmate had been found dead. Pierce states that "the implication, according to the scientists involved, is that chimpanzees continue to feel social bonds, even after death, and feel some sensitivity toward dead bodies" (para. 12).

In The Hidden Life of Wolves, Jim and Jamie Dutcher describe further evidence of animal grieving. After a wolf was killed by a mountain lion, the rest of the pack's behavior shifted dramatically. The Dutchers (2013) noticed that, "[u]ntil that event, seeing the pack coursing through the meadow in a game of tag or keep-away was a daily occurrence, but afterward, [the Dutchers] observed no play for six weeks. The spirit simply left them" (p. 65). Not only did the Dutchers notice the wolves acting differently, they noticed that their howls changed from exuberant to mournful. The wolves appeared to be remembering their lost packmate. 


\subsection{Rituals}

Beyond mere emotional expressions, some small group animals grieve in ritualistic ways. Pierces (2018) notes that elephants take great interest in the bones of other elephants. She writes, "Members of three different elephant families came to visit the body of a deceased matriarch, smelling and touching and repeatedly passing by the corpse" (para. 10). Similarly, Joyce Poole, of the Amboseli Elephant Research Project in Kenya, writes in her essay, "When Bonds are Broken", that elephants are known to carry the bones of dead elephants for long distances, sometimes to return them to the original site of the death. Additionally, elephants are known for trying to help feed their dying companions and covering their dead with leaves.

Orca pods, organized and led much the same as elephant herds, appear to bear grief as deeply. In her essay, "A Death in the Family", Naomi Rose (2000) details how a female orca named Scar was frequently seen swimming with her two sons. After she died, for a day or two "Scar's sons swam together, visiting again and again the place their mother had passed in the last few days of her life" (p. 144). The researchers say that perhaps they were honoring her, desperately searching for her, holding a lonely vigil, or fixing her into their memory. They aren't able to pinpoint the exact reason for this behavior, but whatever the reason it was a clear sign the brother orcas were grieving.

Such rituals of grief are not only seen in mammals, but that of birds as well. Marc Bekoff has observed magpies burying one of their own with twigs and leaves (Pierce, 2018, para. 13). As Bekoff watched, four magpies each laid grass on the corpse, stood together for a few seconds, and then each flew off. It is hard to understand what exactly the birds were thinking or feeling, but it is also hard not to believe that these birds were in some way saying goodbye to their friend.

\subsection{Losing Relationships}

Whether animals process their grief through mere emotional expressions or more formal rituals, it allows them to let go of a significant bond--proof a bond formed in the first place.

\section{Conclusion}

So what relationships do animals form when they are living in small groups? As it turns out, animals form many different bonds, all of them important. Leaders influence the relationships formed in a group. Family relationships help the group survive and thrive. Small group animals even have their own methods of expressing grief when death demands letting go of these bonds.

Of course, researchers continue to study many variations of animal relationships, and some of them we might never know. However, science remains dedicated to understanding these connections. As ethologist Marc Bekoff (2000) writes, "We don't emit clicking sounds as dolphins do because we are not dolphins. Does that mean, however, that we should make no effort to understand dolphins and accept what they have to teach us?" (p. 25). Learning about the animals around us helps us to better live as their neighbors.

Humans are part of a web that connects us to the animals around us. What we do affects them. Bekoff (2000) believes that "[t]he more we know about the nonhuman creatures who share our planet--and the better we both appreciate and respect their emotions--the more we will be able to live with them in civility, equity and accord" (p. 27). We are all connected. Being able to listen to what the animals have to teach us will, indeed, allow us to live with them in civility, equity, and accord. 


\section{References:}

Bekoff, M. (2000). Smile of a dolphin: Remarkable accounts of animal emotions. Discovery Books.

Bekoff, M. (2000). Mixing Science and Emotion. Smile of a dolphin: Remarkable accounts of animal emotions. (pp. 21-27). Discovery Books.

Dutcher, J., \& Dutcher, J. (2013). The Hidden Life of Wolves. National Geographic.

Freeman, L. (n.d.). Teenage elephants need a father figure. BBC. https://www.bbcearth.com/blog/?article=teenage-elephants-need-a-father-figure.

Macdonald, D. (2000). Night School. M. Bekoff (Eds), Smile of a dolphin: Remarkable accounts of animal emotions (pp. 47-29). Discovery Books.

Matriarchal societies in the animal kingdom. (2015, February 4). Springtide whale watching \& eco tours. https://www.victoriawhalewatching.com/matriarchal-societies-in-the-animalkingdom/.

The omega. (n.d.). Living with wolves. https://www.livingwithwolves.org/portfolio/the-omega/.

Pierce, J. (2018) Do Animals Experience Grief? Smithsonian. https://www.smithsonianmag.com/science-nature/do-animals-experience-grief-180970124/.

Poole, J. (2000). When bonds are broken. M. Bekoff (Eds.), Simile of a dolphin: Remarkable accounts of animal emotions (pp. 142-143). Discovery Books.

Rose, N.A. (2000). A death in the family. M. Bekoff (Eds.), Simile of a dolphin: Remarkable accounts of animal emotions (pp. 144) Discovery Books.

Vallejo, D. (2018, July 17). Animal's social behavior: Group living. Zoo portraits. https://www.zooportraits.com/animals-social-behavior-group-living/. 